\title{
Tradução comentada de um clássico de Copérnico
}

\author{
Penha Maria Cardoso Dias ${ }^{1}$ \\ Instituto de Física, Universidade Federal do Rio de Janeiro
}

Tenho por norma não escrever resenhas, mas não pude recusar o simpático convite do editor da Revista Brasileira de Ensino de Física, Professor Nelson Studart. O livro a resenhar é: Commentariolus (Pequeno Comentário de Nicolau Copérnico sobre suas próprias hipóteses acerca dos movimentos celestes), de Nicolau Copérnico (é claro, após o sub-título), com introdução, tradução para o Português e notas de Roberto de Andrade Martins (Editora Livraria da Física, 180 pp, 2a. edição, 2003). Trata-se, segundo Martins, provavelmente, de uma primeira versão do $D e$ Revolutionibus Orbium Calestium (Sobre a Rotação das Esferas Celestes) [1].

O livro de Martins foi publicado, inicialmente, em 1990 e se encontra em sua segunda edição (1993). A primeira edição foi apresentada por Luiz Pinguelli Rosa. Pinguelli discute questões epistemológicas geradas pelo De Revolutionibus, hoje clássicas. Um problema é o do compromisso epistemológico de Copérnico — seria ele um realista, um instrumentalista? — suscitado pelo prefácio, hoje famoso, de Andreas Osiander. Outro problema, não necessariamente independente do primeiro, mas, a mon avis, mais preocupante, é o próprio problema que a Epistemologia se propõe a resolver. Em linguagem que filósofos considerariam chula, tratase do conteúdo de verdade de uma teoria: Pode-se dizer que teorias "são" certas ou erradas? (teorias são ou não epistêmicas?). Caso não se possa, como um cientista escolhe uma dentre teorias que competem?: Simplicidade? A teoria tem um maior poder de predição? [2] O De Revolutionibus é um manancial para essa discussão, como Pinguelli bem explica.

O Commentariolus é difícil de ler, o que é reconhecido por Martins. No livro, Copérnico não apresenta detalhes dos métodos da Astronomia. Ele, apenas, lista aspectos muito gerais dos movimentos dos planetas e da Lua. Martins supre o leitor, na Introdução, com particularidades do sistema astronômico, definindo seu aparato conceitual. Além disso, foi necessário que a edição viesse acompanhada de comentários, em notas de rodapé. Martins baseia-se em uma vasta literatura e o resultado é um trabalho erudito e meticuloso, não só quanto aos comentários, mas também quanto à tradução em si.

Em seu ensaio introdutório, Martins contextualiza, ainda, a obra de Copérnico, em seu tempo. Ele discute outras vêzes em que um sistema heliocêntrico teria sido proposto, na Antigüidade: A mais conhecida, por Aristarco de Samos (século III aC); além disso, alguns autores consideram que Heráclides do Ponto foi um "Tycho Brahe da Antigüidade" [3], por ter considerado um sistema similar ao de Tycho, um híbrido entre o de Cláudio Ptolomeu [4] e o de Copérnico. Embora Martins não se detenha nas questões epistemológicas clássicas associadas ao nome de Copérnico (um objetivo que ultrapassaria o escopo de intenções), o que é feito por Pinguelli, ele discute o que chama de "natureza da obra de Copérnico": Além de colocar o Sol estático no centro do sistema e a Terra girando ao seu redor, que outra contribuição trouxe Copérnico? Martins analisa, então, o sistema de Copérnico, quanto a seus recursos e resultados e o que um astrônomo consideraria o status epistemológico da Astronomia, na época.

Finalmente, Martins toca em uma questão que me é sensível [p.79]:
A falta de conhecimentos detalhados sobre o conteúdo dos trabalhos científicos costuma levar a simplificações en- ganadoras: poderia imaginar que Copérnico simplesmente teve um lampejo e "viu" que o sistema heliocêntrico era o melhor. As coisas não são assim. Copérnico foi admi- rado, estudado e respeitado em sua época pelo alto nível de seu trabalho matemático de detalhe, não por haver simples- mente sugerido uma idéia. E isso é o que o distingue dos "Copérnicos da Antigüidade".

Um argumento comum é que Copérnico colocou o Sol no centro por compromisso com um (neo) platonismo que ressurgia em sua época; de acordo com a idéia, Copérnico "viu" que o Sol, lampada pulcherrima, como a ele se refere Alexandre Koyré ([5], p.63), é o centro do calor e da vida, blá-blá-blá, logo o centro do sistema. O único suporte do argumento parece ser a seguinte passagem do De Revolutionibus ([3], p.527-528), também citada por Thomas Kuhn ([6], p.131]) e parafraseada por Koyré ([5], p.63): ${ }^{1}$

No centro de tudo, repousa o Sol. Pois, quem colocaria essa lâmpada de um belo templo em outro ou melhor lugar do que esse, de onde ela pode iluminar tudo ao mesmo tempo? De fato, é [uma] feliz [expressão] que alguns o chamem de lanterna; outros, de mente e outros, ainda, de piloto do mundo. Trimegisto o chama de "Deus visível"; a Electra de Sófocles, "aquilo que faz arder em chamas todas as coisas". E, assim, o Sol, como se [estivesse] repousando em um trono régio, governa a família dos astros que

${ }^{1}$ Enviar correspondência para Penha Maria Cardoso Dias. E-mail: penha@if.ufrj.br.

Copyright by the Sociedade Brasileira de Física. Printed in Brazil. 
o rodeiam. [...]. A Terra, além disso, é fertilizada pelo Sol e concebe crias todos os anos.

Uma leitura cuidadosa dos originais, seguindo, passo a passo, os argumentos dos autores e o desenvolvimento do raciocínio, em muito contribuiria para nos livrar de tais sandices. Quando menos, essa leitura permitiria separar argumentos realmente relevantes a uma idéia de "argumentos marqueteiros", cujo objetivo, por exemplo, é, tão somente, vender uma idéia que não se sabe justificar. Coube a Johann Kepler o coup de grâce no mundo de inspiração greco-romana, ao substituir os círculos, que representavam a perfeição, pela elipse; ele o fez, não porque a lampada pulcherrima tivesse iluminado seu caminho, de modo que ele "visse", mas porque - por mais que Kepler se esforçasse - Marte se obstinava em seguir os dados de Tycho.

\section{Referências}

[1] Nicolau Copérnico, De Revolutionibus Orbium Calestium (Nuremberg, 1543). Traduzido para o Inglês por Charles
Glenn Wallise editado por R.M. Hutchins, Great Books of the Western World, Encyclopadia Britannica, 54 v., 1952, v. $16,496-838$.

[2] Rom Harré, The Philosophies of Science (An Introductory Survey) (Oxford University Press, 1972, 1985).

[3] Thomas L. Heath, Aristarchus of Samos (The Ancient Copernicus) (Clarendon Press, 1913. Re-publicado por Dover, 1981)

[4] Cláudio Ptolomeu, Ptolemy's Almagest, traduzido para o Inglês e comentado por G.J. Toomer (Princeton University Press, 1998).

[5] Alexandre Koyré, La Révolution Astronomique (Copernic, Kepler, Borelli) (Hermann, 1961; nova impressão, 1974).

[6] Thomas S. Kuhn, The Copernican Revolution (Harvard University Press, 1957). 